\title{
UJI AKTIVITAS ANTIBAKTERI EKSTRAK ETANOL KULIT BUAH ALPUKAT (Persea americana Mill) TERHADAP Staphylococcus aureus ATCC 25923
}

\section{ANTIBACTERIAL ACTIVITY OF AVOCADOS PEEL (Persea americana Mill) EXTRACT ON Staphylococcus aureus ATCC 25923}

\author{
Gelisa Wulandari ${ }^{1}$, Asep Abdul Rahman ${ }^{2 *}$, Rani Rubiyanti ${ }^{3}$ \\ ${ }_{1,2,3}$ Program Studi DIII Jurusan Farmasi, Poltekkes Kemenkes Tasikmalaya, Indonesia. \\ Email: ${ }^{1}$ gelisawulandari97@gmail.com, ${ }^{2 *}$ asep8971@gmail.com, ${ }^{3}$ rani.rubiyanti@yahoo.co.id
}

*koresponding email: asep8971@gmail.com

\begin{abstract}
ABSTRAK
Alpukat (Persea americana Mill) adalah salah satu tanaman obat yang dikenal berkhasiat sebagai antibakteri karena kandungan senyawa antibakteri seperti saponin, alkaloid, dan flavonoid pada buah, biji dan daunnya. Namun, kegunaan kulit alpukat sebagai antibakteri pada Staphylococcus aureus belum diketahui secara pasti. Bakteri Staphylococcus aureus merupakan salah satu bakteri penyebab infeksi terbanyak di dunia. Oleh sebab itu, tujuan penelitian ini dilakukan untuk mengetahui aktivitas antibakteri ekstrak etanol kulit buah alpukat terhadap bakteri Staphylococcus aureus ATCC 25923. Ekstrak kulit buah alpukat diperoleh dengan cara ekstraksi menggunakan metode maserasi yang dilakukan selama tiga kali 24 jam dalam maserator dengan 3 kali pergantian pelarut. Kemudian dilakukan pengujian aktivitas antibakteri ekstrak etanol kulit buah alpukat terhadap Staphylococcus aureus ATCC 25923 dengan menggunakan variasi konsentrasi yaitu $20 \%, 40 \%, 60 \%, 80 \%$, serta kontrol positif menggunakan kloramfenikol $5 \mu \mathrm{g} / \mu \mathrm{L}$ dan kontrol negatif menggunakan etanol $70 \%$. Pengujian ini dilakukan dengan metode difusi kertas cakram. Hasil penelitian menunjukkan bahwa ekstrak etanol kulit buah alpukat dengan nilai rendemen $17,04 \%$ memiliki aktivitas antibakteri terhadap bakteri Staphylococcus aureus ATCC 25923. Konsentrasi 20\% memiliki rata-rata diameter daya hambat $(5,26 \pm 0,63) \mathrm{mm}$, konsentrasi $40 \%(6,1 \pm 0,48) \mathrm{mm}$, konsentrasi $60 \%(6,68 \pm 0,29)$ $\mathrm{mm}$, dan konsentrasi $80 \%(8,05 \pm 0,23) \mathrm{mm}$.
\end{abstract}

Kata Kunci : Aktivitas Antibakteri, Kulit Buah Alpukat, Staphylococcus aureus, Ekstrak Etanol

\begin{abstract}
Avocados (Persea americana Mill) are one of the medicines known to be efficacious because the contains of antibacterial such as saponins, alkaloids, and flavonoids in the fruit, seeds and their leaves. However, avocado's peel using for an antibacterial of Staphylococcus aureus is not known exactly. Staphylococcus aureus is one of the most common bacteria that causes infection in the world. Therefore, the purpose of the study is to determine the antibacterial activity extract ethanol of avocado's peel on Staphylococcus aureus.To get an extract avocado's peel is by using extraction maceration method which is carry out for three times 24 hours in a maserator with three times solvent change. Then the antibacterial activity of the avocado's peel will testing of Staphylococcus aureus ATCC 25923 by using variations concentrations, there are $20 \%, 40 \%, 60 \%, 80 \%$, and then chloramphenicol $5 \mu \mathrm{g} / \mu \mathrm{L}$ as a positive control and ethanol as a negative control. This test is carry out by the paper diffusion method. The results indicate that the ethanol extract of avocado's peel with a 17,04\% yield has antibacterial against of Staphylococcus aureus ATCC 25923 activity. The average inhibitory
\end{abstract}


area concentration of $20 \%$ is $(5,26 \pm 0,63) \mathrm{mm}$, concentration of $40 \%$ is $(6,1 \pm 0,48) \mathrm{mm}$, concentration of $60 \%$ is $(6,68 \pm 0,29) \mathrm{mm}$, and concentration of $80 \%$ is $(8,05 \pm 0,23) \mathrm{mm}$.

Keywords: Antibacteria activity, Avocado's peel, Staphylococcus aureus, Ethanol extract

\section{PENDAHULUAN}

Indonesia adalah negara dengan kekayaan alam yang sangat melimpah, kekayaan alam ini ditandai dengan banyaknya jenis tanaman yang dapat dijadikan sebagai obat tradisional. Obat tradisional semakin banyak diminati oleh masyarakat karena bahannya mudah didapat, mudah diolah dan harganya cukup terjangkau (Aminah et al., 2017).

Salah satu tumbuhan yang dapat dijadikan obat tradisional dan menarik untuk diteliti adalah buah alpukat (Persea americana Mill) dari family Lauraceae yakni tanaman yang berkhasiat sebagai obat, tanaman ini dapat tumbuh di daerah tropis dan subtropis (Katja et al., 2009). Alpukat merupakan salah satu tanaman obat yang dikenal berkhasiat sebagai antibakteri karena kandungan senyawa antibakteri seperti saponin, alkaloid, dan flavonoid pada buah, biji dan daunnya. Selain itu daunnya juga mengandung polifenol, dan buahnya mengandung tanin (Ernawati dan Sari, 2015).

Bakteri Staphylococcus aureus merupakan salah satu bakteri penyebab infeksi terbanyak di dunia. Tingkat keparahan infeksinya pun bervariasi, mulai dari infeksi minor di kulit (furunkulosis dan impetigo), infeksi traktus urinarius, infeksi trakrus respiratorius, sampai infeksi pada mata dan Central Nervous System (CNS) (DeLeo et al., 2010).

Staphylococcus aureus merupakan flora normal pada kulit, saluran pernapasan, dan saluran pencernaan makanan pada manusia. Bakteri ini juga dapat ditemukan di udara dan di lingkungan sekitar.

Resistensi bakteri Staphylococcus aureus terhadap beberapa jenis antibiotik sudah cukup tinggi. Oleh karena itu, perlu dicari bahan alternatif lain yang dapat mengatasi berkembang biaknya bakteri ini (Muchyar et al., 2018), salah satunya adalah dengan memanfaatkan kekayaan alam yang ada di Indonesia.

\section{METODE}

Jenis penelitian ini adalah penelitian eksperimental laboratorium.

\section{Alat}

Alat yang digunakan dalam penelitian adalah maserator, botol kaca, corong, spatula tanduk, inkubator, rotari evaporator, autoklaf, oven, mikropipet, tip mikropipet, cawan uap, cawan petri, hotplate, mikroskop, tisu, kain lap, kertas saring dan alat-alat gelas yang umumnya digunakan di Laboratorium Farmakokimia dan Biologi Farmasi.

\section{Bahan}

Bahan yang digunakan dalam penelitian adalah alkohol $70 \%$, aquadest, bahan-bahan pereaksi (reagen) untuk skrining fitokimia, simplisia kulit alpukat, Nutrient Agar (NA), Nutrient Broth (NB), tisu, kertas saring, blank disc, biakan bakteri Staphylococcus aureus, dan sediaan kapsul antibiotik kloramfenikol $250 \mathrm{mg}$.

\section{Prosedur Penelitian \\ Pengambilan dan Pengolahan Sampel}

Sampel kulit buah alpukat (Persea americana Mill) diperoleh dari Kampung Ganimukti RT 02/03 Desa Santana Mekar, Cisayong, Kota Tasikmalaya, Jawa Barat. Kulit buah alpukat dipisahkan dari daging buah dan bijinya. Kemudian kulit buah alpukat disortasi dan dicuci lalu dikeringkan dibawah sinar matahari langsung. Kulit buah alpukat kering kemudian dihaluskan menggunakan blender dan diayak menggunakan mesh 60 sehingga diperoleh serbuk simplisia kulit buah alpukat sebanyak 619 gram.

\section{Ekstraksi Simplisia}

Sebanyak 200 gram serbuk simplisia kulit buah alpukat diekstraksi dengan menggunakan etanol $70 \%$ sebagai pelarut. Ekstraksi yang dilakukan dalam penelitian ini adalah ekstraksi metode maserasi dengan menggunakan $2 \mathrm{~L}$ pelarut etanol $70 \%$ selama tiga kali 24 jam dengan tiga kali pergantian pelarut dalam maserator. Filtrat yang 
diperoleh dari hasil maserasi 200 gram serbuk simplisia kulit buah alpukat dengan 2 $\mathrm{L}$ pelarut etanol $70 \%$ adalah sebanyak 1,48 L yang kemudian dipekatkan dengan menggunakan rotari evaporator. Rotari evaporator bekerja dengan cara penguapan pelarut dan pemekatan ekstrak. Pemekatan ekstrak dilakukan dengan suhu 40-50 ${ }^{\circ} \mathrm{C}$. Kisaran suhu tersebut diketahui tidak merusak struktur dari senyawa aktif (Irwan, 2011).

\section{Penapisan Fitokimia}

Penapisan fitokimia dilakukan untuk mengetahui adanya kandungan metabolit sekunder terutama senyawa antibakteri yang terkandung dalam ekstrak kulit buah alpukat, diantaranya :

a. Uji Alkaloid

Pengujian alkaloid dilakukan dengan penambahan kloroform dan $\mathrm{HCl}$ pada sampel. Sampel dibagi menjadi tiga bagian. Bagian pertama ditetesi reagen Mayer, hasil positif ditunjukan dengan terbentuknya endapan putih atau kuning. Bagian kedua ditetesi dengan Dragendorff, hasil positif ditunjukan dengan perubahan warna menjadi jingga hingga cokelat, sedangkan bagian ketiga ditetesi dengan pereaksi Bouchardat, hasil positif ditunjukan dengan terbentuknya endapan cokelat sampai hitam (Depkes RI, 1995).

b. Uji Flavonoid

Uji flavonoid dilakukan dengan melarutkan ekstrak sampel kedalam etanol, kemudian ditambahkan $1 \mathrm{~mL} \mathrm{HCl}$ pekat dan $0,1 \mathrm{~g}$ serbuk $\mathrm{Mg}$ serta $2 \mathrm{~mL}$ amil alkohol, dikocok dan dibiarkan memisah. Hasil positif ditunjukan dengan warna merah, kuning, jingga pada lapisan amil alkohol (Depkes RI, 1995).

\section{c. Uji Saponin}

Uji saponin dilakukan dengan memasukkan ekstrak sampel kedalam tabung reaksi, kemudian tambahkan aquadest hingga sampel terendam, didihkan selama 23 menit, dan dinginkan, kemudian kocok secara vertikal selama 10 menit dan biarkan selama 10 detik. Pembentukan busa setinggi $1-10 \mathrm{~cm}$ yang stabil akan terbentuk selama tidak kurang dari 10 menit. Setelah itu ditambahkan 1 tetes $\mathrm{HCl} 2 \mathrm{~N}$, jika busa tersebut tidak hilang menunjukkan adanya saponin (Depkes RI, 1995).

d. Uji Tanin

Uji tanin dilakukan dengan cara menambahkan gelatin $1 \%$ pada sampel, hasil positif ditunjukan dengan terbentuknya endapan (Depkes RI, 1995).

e. Uji Polifenol

Uji polifenol dilakukan dengan cara larutan ekstrak uji sebanyak $1 \mathrm{~mL}$ direaksikan dengan 2-3 tetes larutan $\mathrm{FeCl}_{3} 1 \%$, jika menghasilkan larutan berwarna hijau, merah, ungu, biru tua atau hijau kehitaman maka menunjukkan adanya senyawa polifenol (Depkes RI, 1995).

f. Kuinon

Sebanyak $5 \mathrm{ml}$ sampel dimasukkan ke dalam tabung reaksi, ditambahkan beberapa tetes larutan $\mathrm{NaOH} 1 \mathrm{~N}$. Terbentuknya warna merah menunjukkan adanya senyawa golongan kuinon (Djamil, 2009).

g. Steroid dan Triterpenoid

Sebanyak $5 \mathrm{~mL}$ sampel diuapkan dalam cawan penguap hingga diperoleh residu. Kedalam residu ditambahkan 2 tetes asam asetat anhidrat dan 1 tetes asam sulfat pekat (pereaksi Lieberman-Buchard).

Terbentuknya warna hijau atau merah menunjukkan adanya senyawa golongan steroid atau triterpenoid (Djamil, 2009).

\section{Analisis Data}

Analisis data yang digunakan dalam penelitian ini adalah dengan cara statistik deskriptif, yakni metode analisis dengan melihat perbandingan berbagai konsentrasi ekstrak yang digunakan untuk menghambat aktivitas pertumbuhan bakteri. Data yang diperoleh berupa besarnya diameter daya hambat pada setiap konsentrasi ekstrak. 


\section{HASIL DAN PEMBAHASAN}

\section{Penapisan Fitokimia}

Penapisan fitokimia dilakukuan untuk mengetahui adanya kandungan metabolit sekunder yang terkandung dalam ekstrak kulit buah alpukat.

Tabel 1. Hasil Penapisan Fitokimia Ekstrak Kulit

\begin{tabular}{|c|c|c|c|}
\hline \multicolumn{4}{|c|}{ Buah Alpukat } \\
\hline $\begin{array}{l}\text { Golongan } \\
\text { Senyawa }\end{array}$ & Reagen & Hasil & Pengamatan \\
\hline \multirow[t]{3}{*}{ Alkaloid } & Mayer & $(+)$ & $\begin{array}{l}\text { Endapan } \\
\text { putih }\end{array}$ \\
\hline & Dragendorff & $(+)$ & $\begin{array}{l}\text { Warna dan } \\
\text { endapan } \\
\text { jingga }\end{array}$ \\
\hline & Bouchardat & $(-)$ & $\begin{array}{l}\text { Tidak terdapat } \\
\text { endapan } \\
\text { seharusnya } \\
\text { ada endapan } \\
\text { cokelat }\end{array}$ \\
\hline Flavonoid & $\begin{array}{c}\mathrm{HCl}+\text { serbuk } \\
\text { Mg+Amil } \\
\text { Alkohol }\end{array}$ & $(+)$ & $\begin{array}{l}\text { Berwarna } \\
\text { jingga pada } \\
\text { lapisan } \\
\text { amilalkohol }\end{array}$ \\
\hline Saponin & $\mathrm{HCl} 2 \mathrm{~N}$ & $(+)$ & $\begin{array}{l}\text { Terbentuk } \\
\text { Buih }\end{array}$ \\
\hline Tanin & Gelatin 1\% & $(+)$ & $\begin{array}{l}\text { Endapan } \\
\text { putih }\end{array}$ \\
\hline Polifenol & $\mathrm{FeCl}_{3} 1 \%$ & $(+)$ & $\begin{array}{l}\text { Warna hijau } \\
\text { kehitaman }\end{array}$ \\
\hline Kuinon & $\begin{array}{l}\text { Liberman } \\
\text { Buchard }\end{array}$ & $(-)$ & $\begin{array}{l}\text { Terbentuk } \\
\text { warna cokelat }\end{array}$ \\
\hline $\begin{array}{l}\text { Steroid dan } \\
\text { Triterpenoid }\end{array}$ & $\mathrm{NaOH} 1 \mathrm{~N}$ & $(+)$ & $\begin{array}{l}\text { Terbentuk warna } \\
\text { merah }\end{array}$ \\
\hline
\end{tabular}

Keterangan:

$(+)=$ Mengandung golongan senyawa yang terdentifikasi $(-)=$ Tidak mengandung golongan senyawa yang terdentifikasi

Penapisan fitokimia yang pertama yaitu uji alkaloid. Uji ini bertujuan untuk mengetahui adanya senyawa golongan alkaloid dengan menggunakan pereaksi warna Mayer, Dragendorff dan Bouchardat. Hasil uji alkaloid dengan menggunakan Mayer menghasilkan larutan dengan warna jingga dengan endapan warna putih keabu-abuan, diperkirakan endapan tersebut merupakan kompleks kalium-alkaloid. Pada pembuatan pereaksi Mayer, larutan merkurium (II) klorida ditambah kalium iodida akan bereaksi membentuk endapan merah merkurium (II) iodida. Jika kalium iodida yang ditambahkan berlebih maka akan terbentuk kalium tetraiodomerkurat (II). Alkaloid mengandung atom nitrogen yang mempunyai pasangan elektron bebas sehingga dapat digunakan untuk membentuk ikatan kovalen koordinasi dengan ion logam. Pada uji alkaloid dengan pereaksi Mayer, diperkirakan nitrogen pada alkaloid akan bereaksi dengan ion logam $\mathrm{K}+$ dari kalium tetraiodomerkurat (II) membentuk kompleks kalium-alkaloid yang mengendap.

Pengujian selanjutnya dengan menggunakan Dragendorff menghasilkan endapan dan larutan berwarna jingga yang terlihat berbeda dari warna asalnya, endapan tersebut berasal dari ion logam $\mathrm{K}^{+}$ membentuk ikatan kovalen koordinasi dengan alkaloid sehingga membentuk kompleks kalium-alkaloid yang mengendap.

Selanjutnya pengujian dengan menggunakan Bouchardat, pada pengujian ini hasilnya menyatakan negatif karena tidak terdapat endapan, hal ini diduga disebabkan karena pereaksi Bouchardat yang digunakan sudah tidak stabil karena telah terlalu lama disimpan, seharusnya dibuat segar hal ini disebabkan keterbatasan bahan pereaksi yang ada. Dari ketiga pengujian tersebut dapat disimpulkan bahwa kulit buah alpukat mengandung alkaloid, karena dua dari tiga pereaksi menyatakan hasil yang positif.

Pengujian kedua yaitu uji flavonoid, hasil dari pengujian ini terbentuk warna jingga pada lapisan amilalkohol yang menandakan adanya flavonoid, hal ini disebabkan karena logam $\mathrm{Mg}$ dan $\mathrm{HCl}$ pekat berfungsi untuk mereduksi inti benzonpiron yang terdapat dalam struktur flavonoid sehingga terbentuk garam flavilium yang berwarna jingga akibat dari reduksi oleh asam klorida pekat dan magnesium.

Pengujian metabolit sekunder ketiga yaitu uji saponin, hasilnya menunjukan terbentuk buih yang hilang dengan penambahan $\mathrm{HCl}$. Timbulnya buih menunjukkan adanya glikosida pada kulit buah alpukat yang mempunyai kemampuan membentuk buih dalam air yang terhidrolisis menjadi glukosa dan senyawa lainnya (Marliana et al., 2005).

Pengujian keempat yaitu uji tanin, Hasilnya membentuk endapan putih. Hal ini terjadi karena adanya ikatan hidrogen antara gugus hidroksi tanin pada kulit buah alpukat dengan gugus karbonil protein pada gelatin. 
Pengujian metabolit sekunder kelima adalah uji polifenol, hasil dari pengujian ini terjadinya perubahan warna pada sampel menjadi hijau kehitaman, hal ini timbul karena penambahannya $\mathrm{FeCl}_{3} 1 \%$ pada sampel bereaksi dengan salah satu gugus hidroksil yang ada pada senyawa polifenol dalam kulit buah alpukat. Hasil reaksi itulah yang akhirnya menimbulkan warna (Sangi et al, 2008).

Pengujian keenam adalah uji kuinon, hasil pengujian menunjukkan perubahan warna menjadi cokelat, hal ini berbeda dari literatur yang menyatakan bahwa hasil positif ditunjukkan dengan adanya perubahan warna menjadi merah, sehingga dapat dikatakan bahwa pada kulit buah alpukat tidak mengandung senyawa kuinon.

Pengujian ketujuh adalah steroid dan triterpenoid, hasil yang diperoleh menunjukkan adanya warna merah yang terbentuk dan sedikit warna hijau kebiruan pada dinding cawan yang ditetesi pereaksi, hal ini menandakan bahwa pada ekstrak kulit buah alpukat mengandung senyawa steroid dan triterpenoid. Reaksi triterpenoid dengan pereaksi Liebermann menghasilkan warna merah-ungu sedangkan steroid memberikan warna hijau-biru. Hal ini didasari oleh kemampuan senyawa triterpenoid dan steroid membentuk warna oleh $\mathrm{H}_{2} \mathrm{SO}_{4}$ dalam pelarut asam asetat anhidrid. Perbedaan warna yang dihasilkan oleh triterpenoid dan streoid disebabkan perbedaan gugus pada atom C-4.

Data yang diperoleh dari hasil penapisan fitokimia tersebut menunjukan bahwa ekstrak kulit buah alpukat mengandung metabolit sekunder berupa alkaloid, flavonoid, saponin, tanin dan polifenol. Hal ini membuktikan bahwa etanol sebagai pelarut polar berhasil menarik senyawa-senyawa metabolit sekunder tersebut dari tanaman alpukat khususnya bagian kulit buah alpukat.

\section{Uji Aktivitas Antibakteri}

Pengujian aktivitas antibakteri ekstrak etanol kulit buah alpukat dilakukan dengan menggunakan metode difusi kertas cakram, metode ini dilakukan untuk mengetahui diameter daya hambat yang terbentuk oleh ekstrak etanol kulit buah alpukat dalam menghambat pertumbuhan bakteri Staphylococcus aures ATCC 25923. Hasil pengujian aktivitas antibakteri ekstrak etanol kulit buah alpukat terhadap bakteri Staphylococcus aureus ATCC 25923 ini diperoleh dengan cara mengukur diameter daya hambat yang terbentuk di sekitar kertas cakram berupa zona bening dengan menggunakan jangka sorong.

Tabel 2. Hasil Uji Aktivitas Antibakteri

\begin{tabular}{|c|c|c|c|c|c|}
\hline \multirow{2}{*}{$\begin{array}{l}\text { Konsentr } \\
\text { asi }\end{array}$} & \multicolumn{3}{|c|}{ Pengujian (mm) } & \multirow{2}{*}{$\begin{array}{c}\text { Rata-rata } \\
\text { DDH } \pm \\
\text { SD }(\mathbf{m m})\end{array}$} & \multirow[b]{2}{*}{ Ket } \\
\hline & 1 & 2 & 3 & & \\
\hline $\begin{array}{c}\text { Kontrol } \\
(+)\end{array}$ & 19 & 19,46 & 19,35 & $\begin{array}{c}19,27 \pm \\
0,24\end{array}$ & Kuat \\
\hline Kontrol (-) & 0 & 0 & 0 & 0 & - \\
\hline $20 \%$ & 5,7 & 5,35 & 4,75 & $\begin{array}{c}5,26 \pm \\
0,63\end{array}$ & Sedang \\
\hline $40 \%$ & 6,25 & 6,49 & 5,56 & $6,1 \pm 0,48$ & Kuat \\
\hline $60 \%$ & 6,35 & 6,85 & 6,85 & $\begin{array}{c}6,68 \pm \\
0,29\end{array}$ & Kuat \\
\hline $80 \%$ & 8,1 & 7,81 & 8,25 & $\begin{array}{c}8,05 \pm \\
0,23\end{array}$ & Kuat \\
\hline
\end{tabular}

Keterangan:

Kontrol $(+)=$ Klorampenikol $5 \mu \mathrm{g} / \mu \mathrm{L}$

Kontrol (-) = Etanol $70 \%$

$\mathrm{SD}=$ Standar Deviasi

$\mathrm{DDH}=$ Diameter Daya Hambat

Berdasarkan hasil pengujian aktivitas antibakteri terhadap ekstrak etanol kulit buah alpukat tersebut diperoleh nilai rata-rata diameter kelompok ekstrak lebih besar dari diameter kontrol negatif, sehingga dapat disimpulkan bahwa ekstrak kulit buah alpukat memiliki aktivitas antibakteri terhadap pertumbuhan bakteri Staphylococcus aureus ATCC 25923. Kontrol negatif yang digunakan dalam penelitian ini adalah etanol $70 \%$ yang juga digunakan sebagai pelarut dalam pengenceran ekstrak kulit buah alpukat. Kontrol negatif pada penelitian ini memiliki diameter $6 \mathrm{~mm}$ yang sesuai dengan diameter kertas cakram, hal ini menunjukan bahwa dalam kontrol negatif tidak terdapat zona hambat atau aktivitas antibakteri. Dengan demikian, zona hambat yang dihasilkan ekstrak etanol kulit buah alpukat dalam menghambat pertumbuhan bakteri Staphylococcus aureus ATCC 25923 pada masing-masing konsentrasi ekstrak merupakan aktivitas senyawa metabolit sekunder yang terdapat dalam kulit buah alpukat.

Jika dikaitkan dengan ketentuan penggolongan zona hambat antibakteri yang dikemukaan oleh Pan et al (2009) zona hambat yang terbentuk $<3 \mathrm{~mm}$ dianggap 
memiliki aktivitas daya hambat lemah, 3-6 $\mathrm{mm}$ dinyatakan memiliki aktivitas daya hambat sedang, >6 mm dinyatakan memiliki aktivitas daya hambat kuat. Kriteria aktivitas daya hambat dari ekstrak etanol kulit buah alpukat pada konsentrasi $20 \%$ termasuk dalam kriteria sedang karena memiliki aktivitas daya hambat 3-6 $\mathrm{mm}$, sedangkan konsentrasi $40 \%$, 60\% dan $80 \%$ dianggap memiliki aktivitas daya hambat kuat karena zona hambat yang terbentuk $>6 \mathrm{~mm}$.

Pada setiap variasi konsentrasi diperoleh diameter daya hambat yang berbeda. Semakin tinggi konsentrasi ekstrak etanol kulit buah alpukat, semakin besar pula diameter daya hambat yang terbentuk dan begitupun sebaliknya, hal ini diduga semakin tinggi konsentrasi ekstrak yang digunakan, maka jumlah senyawa antibakteri yang dilepaskannya pun akan semakin besar dan mempermudah penetrasi senyawa-senyawa metabolit sekunder masuk ke dalam sel bakteri dengan mekanismenya masingmasing. Terbentuknya zona hambat disekitar kertas cakram menunjukan bahwa ekstrak ini mengandung senyawa yang bersifat sebagai antibakteri. Pada ekstrak diketahui mengandung senyawa alkaloid, flavonoid, saponin, tanin dan polifenol.

Mekanisme kerja senyawa alkaloid sebagai antibakteri yaitu melakukan penghambatan dengan mengganggu komponen penyusun peptidoglikan pada sel bakteri, sehingga lapisan dinding sel tidak terbentuk secara untuh dan menyebabkan kematian sel. Sementara flavonoid bekerja dengan cara membentuk kompleks protein ekstraseluler yang mengganggu integritas membran sel bakteri. Sedangkan saponin bekerja dengan meningkatkan permeabilitas membran sehingga terjadi hemolisis sel, apabila saponin berinteraksi dengan sel bakteri maka sel bakteri tersebut akan rusak atau lisis. Tanin mempunyai aktivitas antibakteri dengan cara mengkerutkan dinding sel atau membran sel sehingga permeabilitas bakteri terganggu yang mengakibatkan sel bakteri tidak mampu melakukan aktivitas hidup sehingga pertumbuhannya terhambat. Sementara polifenol berperan sebagai toksin dalam protoplasma, merusak dan menembus dinding sel serta mengendapkan protein sel bakteri. Selanjutnya mekanisme kerja steroid sebagai antibakteri berhubungan dengan membran lipid dan sensitivitas terhadap komponen steroid yang menyebabkan kebocoran pada liposom. Steroid dapat berinteraksi dengan membran fosfolipid sel yang bersifat permeabel terhadap senyawasenyawa lipofilik sehingga menyebabkan integritas membran menurun serta morfologi membran sel berubah yang menyebabkan sel rapuh dan lisis (Lenny, 2016).

\section{SIMPULAN DAN SARAN}

Berdasarkan penelitian yang telah dilakukan dapat disimpulkan bahwa ekstrak etanol kulit buah alpukat (Persea Americana Mill) dengan rendemen $17,04 \%$ pada konsentrasi $20 \%$, 40\%, $60 \%$ dan $80 \%$ menunjukkan adanya aktivitas antibakteri terhadap pertumbuhan bakteri Staphylococcus aureus ATCC 25923 pada media Nutrient Agar dengan metode difusi kertas cakram. Pada konsentrasi $20 \%$ ratarata diameter daya hambat antibakteri yaitu $(5,26 \pm 0,63) \mathrm{mm}$, konsentrasi $40 \%(6,1 \pm$ $0,48) \mathrm{mm}$, konsentrasi $60 \%(6,68 \pm 0,29) \mathrm{mm}$, dan konsentrasi $80 \%(8,05 \pm 0,23) \mathrm{mm}$.

Perlu dilakukan penelitian lebih lanjut mengenai potensi antibakteri pada kulit buah alpukat dengan melakukan isolasi senyawa yang terkandung dalam ekstrak etanol kulit buah alpukat untuk mencari senyawa yang dapat menghambat pertumbuhan bakteri Staphylococcus aureus ATCC 25923. Perlu dilakukan penelitian lebih lanjut mengenai uji efektifitas ekstrak etanol kulit buah alpukat terhadap bakteri Staphylococcus aureus.

\section{DAFTAR PUSTAKA}

Aminah, T., Nurhayati, dan Abidin, Z., 2017, Penetapan Kadar Flavonoid Total Ekstrak Etanol Kulit Buah Alpukat (Persea americana Mill.) dengan Metode Spektrofotometri Uv-Vi, Jurnal Fitofarmaka Indonesia, Vol. 4, No. 2, hh. 226-229.

DeLeo, F.R., Otto, M., Kreiswirth, B.N., and Chambers, H.F., 2010, Communityassociated meticillin-resistant Staphylococcus aureus, Laboratory of 
Human Bacterial Pathogenesis, Rocky Mountain Laboratories, National Institute of Allergy And Infectious Diseases, National Institutes of Health, Hamilton, MT 59840, USA.

Depkes R.I., 1995, Materia Medika Indonesia Jilid VI, Departemen Kesehatan Republik Indonesia, Jakarta.

Djamil, R., Anelia, T., 2009, Penapisan Fitokimia Uji, BSLT dan Uji Antioksidan Ekstrak Metanol beberapa Spesies Papilionaceae, Jurnal IImu Kefarmasian Indonesia, Vol.7, No.1, 65-67.

Ernawati, Sari, K., 2015, Kandungan Senyawa Kimia dan Aktivitas Antibakteri Ekstrak Kulit Buah Alpukat (Persea americana Mill) terhadap Bakteri Vibrio alginolyticus, Jurnal Kajian Veteriner, Vol. 3, No. 2, hh. 203-211.

Katja, D.G., Suryanto, E., dan Wehantouw, F., 2009, Potensi Daun Alpukat (Persea americana Mill.) sebagai Sumber Antioksidan Alami, Chemistry Progress 2(1), hh. 58-64.

Lenny, Astri, A., 2016, Daya Hambat Ekstrak Buah Alpukat (Persea americana Mill.) terhadap Pertumbuhan Staphylococcus aureus dan Staphylococcus epidermidi, Skripsi, Program Sarjana Terapan Analis Kesehatan, Universitas Muhammadiyah Semarang, Semarang.

Muchyar, D.S.R., H, C, Damajanty dan Pangemanan, A.S.R.S., 2018, Uji Daya Hambat Perasan Daging Buah Alpukat (Persea americana Mill.) terhadap Pertumbuhan Bakteri Staphylococcus aureus, Jurnal e-GiGi (eG), Vol. 6, No. 1, hh. 34-35.

Irwan, Fahry., 2011, Aktivitas Antidiabetes dan Analisis Fitokimia Ekstrak Air dan Etanol Daun Wungu (Graptophyllum pictum (L.) Griff.), Skripsi, Departement Biokimia, Institut Pertanian Bogor, Bogor.

Pan, Xiaodong., Chen, F., Wu, T., Tang, H., Zhao, Z., 2009, The Acid Bile Tolerance and Antimicrobial Property of Lactobacillus acidophilus NIT, Jurnal Zhejiang University, Hangzhou, China, hal 599.

Sangi, M., M. R. J. Runtuwene., H. E. I. Simbala dan V. M. A, 2008, Analisis Fitokimia Tumbuhan Obat di Kabupaten
Minahasa Utara, Chem. Prog. Vol. 1, No. 1, hh. 51-53. 